\title{
A remarkable new species of Agoristenidae (Arachnida, Opiliones) from Córdoba, Colombia
}

\author{
Andrés F. García' \& María Raquel Pastrana-M. ${ }^{2}$ \\ 1 Universidade Federal do Rio de Janeiro (UFRJ), Museu Nacional (MN), Departamento de Invertebrados. Rio de Janeiro, RJ, Brasil. \\ ORCID: http://orcid.org/0000-0001-6705-3498. E-mail: agarciarinc@gmail.com \\ 2 Universidad de Córdoba (UNICOR), Departamento de Biología, Grupo de Investigación de Biodiversidad. Montería, Córdoba, Colombia. \\ ORCID: http://orcid.org/0000-0003-3473-7986. E-mail: mariaraquelpm@gmail.com
}

\begin{abstract}
A new species of Leiosteninae (Opiliones, Agoristenidae) from the Colombian Caribbean, Avima tuttifrutti sp. nov. García \& Pastrana-M., is described and illustrated, based on two males from the montante forests of Tierralta (Córdoba department). The new species differs externally from other species of Avima by having one yellow hump on mesotergal area IV and green coloration on dorsal scutum. SEM images of the penis and a map showing its distribution are offered. This species represents the first record of a harvestman from the department of Córdoba and the eighth species of the subfamily recorded from the country.
\end{abstract}

Keywords. Caribbean; Harvestmen; Humid forest; Laniatores; Leiosteninae.

\section{INTRODUCTION}

Agoristenidae Šilhavý, 1973 is a Neotropical family of the order Opiliones, with 26 genera and 78 especies (Ahumada et al., 2020; García \& Kury, 2020; Kury, 2018). Leiosteninae Šilhavý, 1973 is the most diverse subfamily within Agoristenidae, with 12 genera and 60 species, distributed in northern South America (Brazilian Amazon, French Guiana, Suriname, Guyana, Trinidad and Tobago, Venezuela, Colombia and northern Peru) (Kury 2013; García \& Kury, 2020; García \& Villarreal, 2020). In Colombia, Leiosteninae is represented by six genera and seven species: Andrescava Roewer, 1957 (1 sp.), Avima Roewer, 1949 (1 sp.), Barinas González-Sponga, 1987 (1 sp.), Leptostygnus Mello-Leitão, 1940 (2 spp.), Nemastygnus Roewer, 1929 (1 sp.), and Vima Hirst, 1912 (1 sp.) (the record of Sabanilla Roewer, 1913 in Atlántico department is dubious, according to Kury (2003) and is not considered here) (Ahumada-C. et al., 2020; García \& Kury, 2020; Kury, 2003).

Avima is the most diverse genus of the subfamily, with 34 described species, distributed from northern Brazil and Peru to Trinidad and Tobago and the Caribbean region of Venezuela (García \& Villarreal, 2020: fig. 9), and has been considered as a non-natural aggrupation of species. Because of that, a cladistic analysis is needed for a better understanding of its phylogenetic affinities and real distribution (Porto \& Colmenares, 2014; García \& Villarreal, 2020). In Colombia, there is only one species of the genus recorded, Avima scabra (Roewer, 1963), from Cundinamarca department (central Andes).

As a result of a field trip to the buffer zone of Paramillo National Natural Park (Tierralta, Córdoba), a remarkable new species of Avima was collected. Here, we offer a description and illustrations of the species together with a distribution map.

\section{MATERIAL AND METHODS}

Individuals were photographed using a Leica M205C stereoscope attached to a Leica DFC450 digital camera. All photos were combined with the Leica Application Suite (LAS) Version 4.6.2 software and posteriorly edited in Photoshop CC 2014 software. Drawings of the species were made using a stereomicroscope with camera lucida, and digitized with Inkscape 0.91 software. Color descriptions use the standard names of the 954 RGB monitor colors from the XKCD Color Survey proposed by Randall Munroe (https:// xkcd.com/color/rgb). The penis of the new species was dehydrated with Critical Point Drying (CPD), sputter coated with gold and examined with SEM on a JEOL JSM-6390LV microscope belonging to Rudolf Barth Electron Microscopy Platform of the Oswaldo Cruz Institute/Fiocruz.

The map was made using Quantum GIS 3.10.1 software (QGIS Development Team, 2018). Biogeographic units used here are from the WWF 
Terrestrial Eco-regions of the World (Olson et al., 2001). Geographic coordinates were interpolated between square brackets to indicate that they are estimates, using GoogleMaps. The word vereda refers to a subdivision of a municipality or village in Colombia and has no direct translation to English.

The morphological terminology follows Kury \& Medrano (2016) for dorsal scutum shape and Kury \& Villarreal (2015) for macrosetae of male genitalia. Morphometric abbreviations are: (AL) abdominal scutum length, (AW) maximum abdominal scutum width, (BaCh) basichelicerite length, (CL) carapace length, (CW) maximum carapace width, (DS) dorsal scutum, (Fe) femur, (LP) lamina parva, (Ma) malleus, (MS) macrosetae of penis, (Mt) metatarsus, $(\mathrm{Pa})$ patella, (Ta) tarsus, (Ti) tibia, (TL) total length, (VP) ventral plate. All measurements are in $\mathrm{mm}$ unless otherwise noted. The type material is deposited in Instituto de Ciencias Naturales, Universidad Nacional de Colombia, Bogota, Colombia (ICN) (curator: Eduardo Flórez), and Museu Nacional, Universidade Federal do Rio de Janeiro, Rio de Janeiro, Brazil (MNRJ) (curator: Adriano Kury).

\section{RESULTS}

\section{Avima tuttifrutti sp. nov.}

(Figs. 1-4)

Diagnosis: Avima tuttifrutti sp. nov. can be distinguished by the presence of a green coloration on laterals and posterior margin of DS (Figs. 1A-D, 2A, B); and area IV with a medial yellow hump (Figs. 1C, D, 2B) (not present in other
Avima species); stylus of penis without dorsal process or dorsal keel (Fig. 3) (Avima leucobunus Roewer, 1929 has dorsal keel).

Description: Based on male holotype (Measurements in Table 1).

Dorsum: DS epsilon type, with wrinkled tegument. Green coloration beginning at ozopore level and reaching the posterior margin of the scutum (except in the proximal half of mesotergal areas I-III and area $\mathrm{V}$ ) and free tergites (Figs. 1A, C, D, 2A, B). Area IV with a medial hump (Figs. 1C, D, 2B). Green coloration, except on laterals of cephalothorax and in the hump of area IV, in which is yellow (Figs. 1A, C, 2A, B). Ocularium low, without median concavity, with some granules. Mesotergum weakly delimited, divided into four areas with diffuse grooves, mostly smooth (Figs. 1A, 2A). Abdominal scutum widest at level of groove III. Area I-IV smooth with two medial subparallel granules. Area I divided in two halves; area II-IV undivided. Free tergites I-III with some granules (Figs. 1A, 2A, B).

Venter: Coxa I with one anteroproximal large triangular tubercle with four cusps, a longitudinal curved row of nine medium-sized tubercles (the two distalmost visible in dorsal view) and two tubercles on the postero-distal margin (Fig. 2C). Coxa Il with a row of tubercles on the distal third. Coxae III-IV with some granules. Coxa IV longer than coxa III stigmatic area with a few granules. (Fig. 1B).

Chelicera: Basichelicerite rectangular, with well-marked bulla; four tubercles on ectal face and two tubercles on

Table 1. Measurements (in mm) of Avima tuttifrutti sp. nov. types. Abbreviations: $A L=$ abdominal scutum length; $A W=$ Maximum abdominal scutum width; $\mathrm{BaCh}=$ Basichelicerite length; $\mathrm{CL}=$ Carapace length; $\mathrm{CW}=$ Maximum carapace width; $\mathrm{DSL}=$ Dorsal scutum length; $\mathrm{Fe}=\mathrm{Femur} ; \mathrm{IOD}=\mathrm{Interocular}$ distance; $\mathrm{Mt}=$ Metatarsus; $\mathrm{Pa}=$ Patella; $\mathrm{Ta}=$ Tarsus; $\mathrm{TBL}=$ Total body length (DSL + free tergites); $\mathrm{Ti}=$ Tibia; $\mathrm{TL}=$ Total length; $\mathrm{Tr}=\mathrm{Trochanter}$.

\begin{tabular}{|c|c|c|c|}
\hline Structure & Measurement & $\begin{array}{l}\text { Male Holotype } \\
\text { ICN-A0-1970 }\end{array}$ & $\begin{array}{c}\text { Male Paratype } \\
\text { MNRJ } 59051\end{array}$ \\
\hline \multirow[t]{8}{*}{ Body } & AL & 1,51 & 1,61 \\
\hline & AW & 2,17 & 2,08 \\
\hline & $\mathrm{BaCh}$ & 0,43 & 0,47 \\
\hline & $\mathrm{CL}$ & 1,10 & 1,15 \\
\hline & CW & 1,99 & 1,87 \\
\hline & DSL & 2,61 & 2,76 \\
\hline & IOD & 0,58 & 0,62 \\
\hline & TL & 3,12 & 3,26 \\
\hline \multirow[t]{6}{*}{ Pedipalp } & $\mathrm{Tr}$ & 0,67 & 0,54 \\
\hline & $\mathrm{Fe}$ & 1,12 & 0,65 \\
\hline & $\mathrm{Pa}$ & 0,58 & 0,49 \\
\hline & $\mathrm{Ti}$ & 0,61 & 0,82 \\
\hline & Ta & 0,77 & 0,83 \\
\hline & TL & 3,75 & 3,33 \\
\hline \multirow[t]{7}{*}{ Leg I } & $\mathrm{Tr}$ & 0,31 & 0,37 \\
\hline & $\mathrm{Fe}$ & 6,35 & 5,45 \\
\hline & $\mathrm{Pa}$ & 0,64 & 0,66 \\
\hline & $\mathrm{Ti}$ & 4,32 & 4,08 \\
\hline & Mt & 8,81 & 8,17 \\
\hline & Ta & 1,29 & 1,49 \\
\hline & TL & 21,72 & 20,22 \\
\hline
\end{tabular}

\begin{tabular}{|c|c|c|c|}
\hline Structure & Measurement & $\begin{array}{c}\text { Male Holotype } \\
\text { ICN-Ao-1970 }\end{array}$ & $\begin{array}{c}\text { Male Paratype } \\
\text { MNRJ } 59051 \\
\end{array}$ \\
\hline \multirow[t]{7}{*}{ Leg II } & $\mathrm{Tr}$ & 0,47 & 0,46 \\
\hline & $\mathrm{Fe}$ & 12,90 & 12,06 \\
\hline & $\mathrm{Pa}$ & 0,90 & 1,02 \\
\hline & $\mathrm{Ti}$ & 11,66 & 10,72 \\
\hline & Mt & 18,31 & 17,04 \\
\hline & Ta & 3,77 & 3,34 \\
\hline & TL & 48,01 & 44,64 \\
\hline \multirow[t]{7}{*}{ Leg III } & $\mathrm{Tr}$ & 0,64 & 0,64 \\
\hline & $\mathrm{Fe}$ & 8,81 & 8,38 \\
\hline & $\mathrm{Pa}$ & 1,20 & 1,02 \\
\hline & $\mathrm{Ti}$ & 5,28 & 4,98 \\
\hline & Mt & 10,89 & 9,54 \\
\hline & Ta & 1,86 & 1,86 \\
\hline & TL & 28,68 & 26,42 \\
\hline \multirow[t]{7}{*}{ Leg IV } & $\operatorname{Tr}$ & 0,73 & 0,68 \\
\hline & $\mathrm{Fe}$ & 12,74 & 12,32 \\
\hline & $\mathrm{Pa}$ & 1,19 & 1,26 \\
\hline & $\mathrm{Ti}$ & 7,29 & 6,90 \\
\hline & Mt & 16,59 & 14,68 \\
\hline & $\mathrm{Ta}$ & 2,31 & 1,94 \\
\hline & TL & 40,85 & 37,78 \\
\hline
\end{tabular}


the posterior margin. Chelicera swollen (Figs. 1A, 1B). Anterior region of hand with setiferous tubercles of different sizes, going from the middle of the hand to the base of movable and fixed fingers. Fixed finger with the inner surface finely grooved. Movable finger with one trapezoidal, medial tooth and with the inner surface at distal portion dentate (Fig. 2D).

Pedipalps: Trochanter ventrally with two subapical tubercles. Femur with a ventroectal row of four setiferous
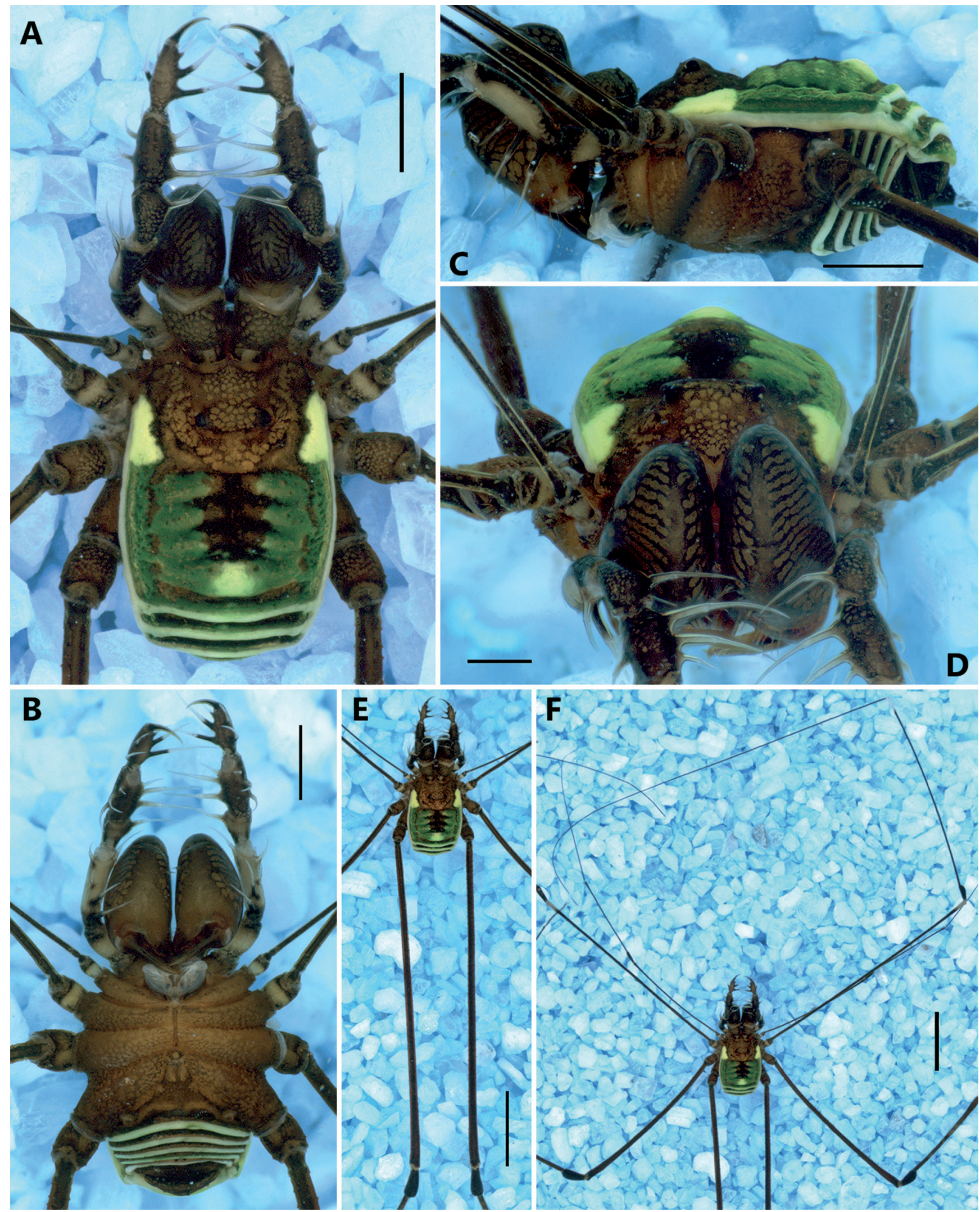

Figure 1. Holotype habitus of Avima tuttifrutti sp. nov. (ICN-A0-1970). (A) Dorsal view. (B) Ventral view. (C) Lateral view. (D) Frontal view. (E) Panoramic view, showing femora IV. (F) Panoramic view, showing the extremely elongate and slender leg II. Scale bar: $A-C=1 \mathrm{~mm} ; D=0.5 \mathrm{~mm} ; E, F=3 \mathrm{~mm}$. 
tubercles (the two basalmost larger than the others, and one medium ventromesal setiferous tubercle in the apical portion. Patella with one large mesal setiferous tubercle. Tibia ectal ill, mesal Ili. Tarsus ectal Ili, mesal Ili (Figs. 2E, F).

Legs: Leg I filiform, legs I-IV straight and smooth (Figs. 1A, E-F). Leg II unusually elongate and slender (Fig. 1F). Distal portion of Fe II, Ti II and Ti IV with yellowish coloration. Leg IV thicker than the others; Fe IV length five times DS length (Fig. 1E). Ta IV without tarsal process, claws smooth. Tarsal formula: $\sigma^{7}$ holotype (ICNAo-1970): 10-9/13-17/7-6/7-7; o' paratype (MNRJ 59051): 9-9/17-17/6-7/7-7.
Penis: lamina parva (LP) small and depressed, apex crescent shaped, with anterolateral sharp corners dorsoapically pointed (Fig. 3). Malleus with two pairs of branched MS and one pair of branched MS B transversally aligned (Figs. 3A, B); MS C absent; two pairs of MS D located in a keel between the ventral part of the LP and the base of the stylus (Figs. 3A, C); MS E2 large and triffid, MS E1 absent (Fig. 3A). Stylus elongated, (surpassing the LP), mostly straight, with sinuous distal half, tip truncated and straight (Figs. 3B, C).

Color (in alcohol): Carapace, chelicerae, pedipalpi and legs I-IV background Burnt Sienna (\#b04e0f) with reticulation
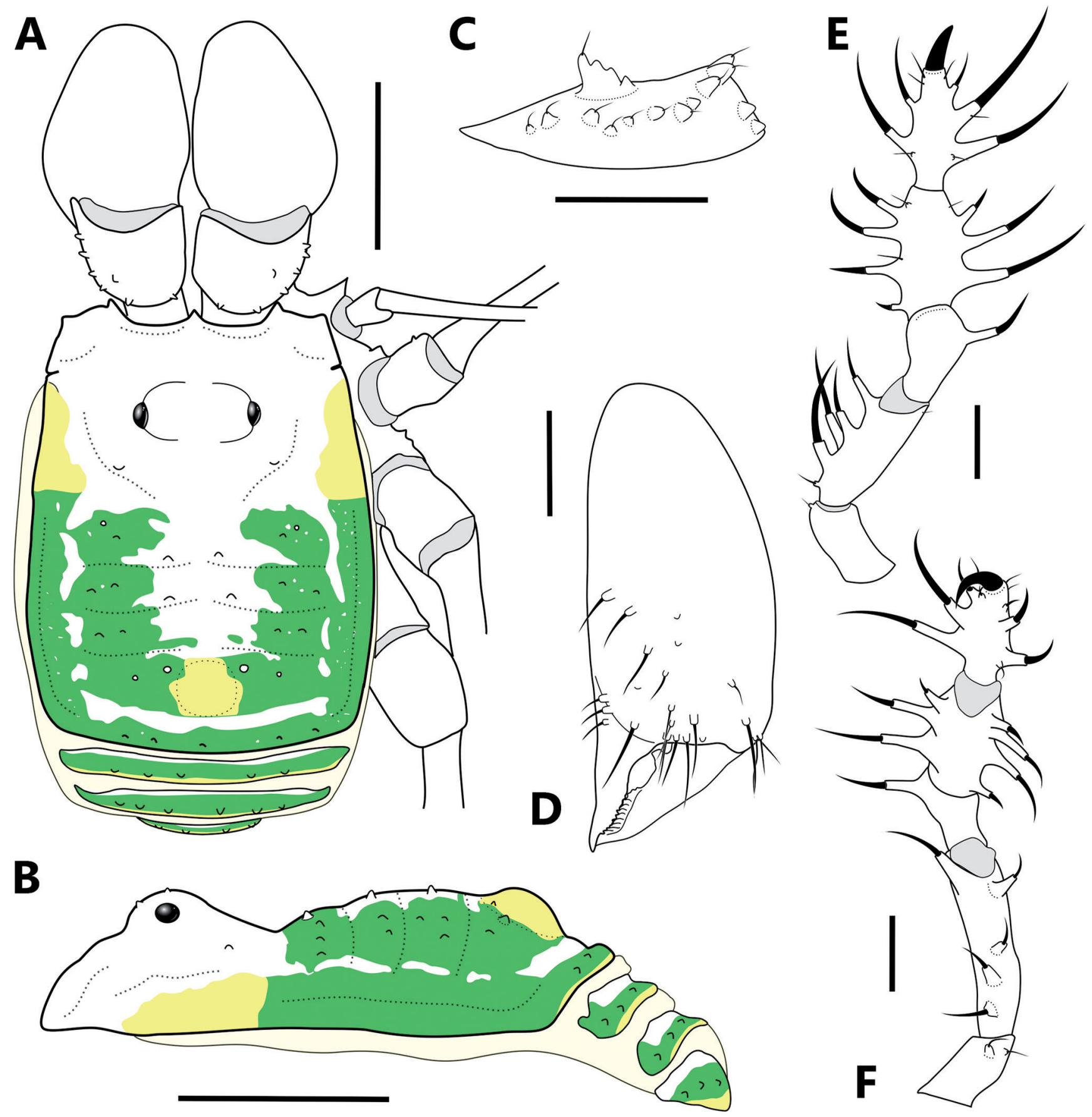

Figure 2. Drawings of the holotype of Avima tuttifrutti sp. nov. (ICN-A0-1970). (A) Habitus, dorsal view. (B) Same, lateral view. (C) Coxa I, ventral view. (D) Left chelicera, frontal view. (E) Left pedipalp, mesal view, (F) Same, ectal view. Scale bar: $A, B=1 \mathrm{~mm} ;(-F=0.5 \mathrm{~mm}$. 
Reddish Brown (\#7f2b0a). Lateral borders of mesotergum, external region of areas I-IV and free tergites Vibrant Green (\#0add08). Laterals of cephalothorax and medial protuber- ance of area IV Greenish Yellow (\#cdfd02). Trochanter and femur of pedipalps, trochanters I-II, distal femora II and distal tibiae II and IV Banana Yellow (\#fafe4b) (Fig. 1).

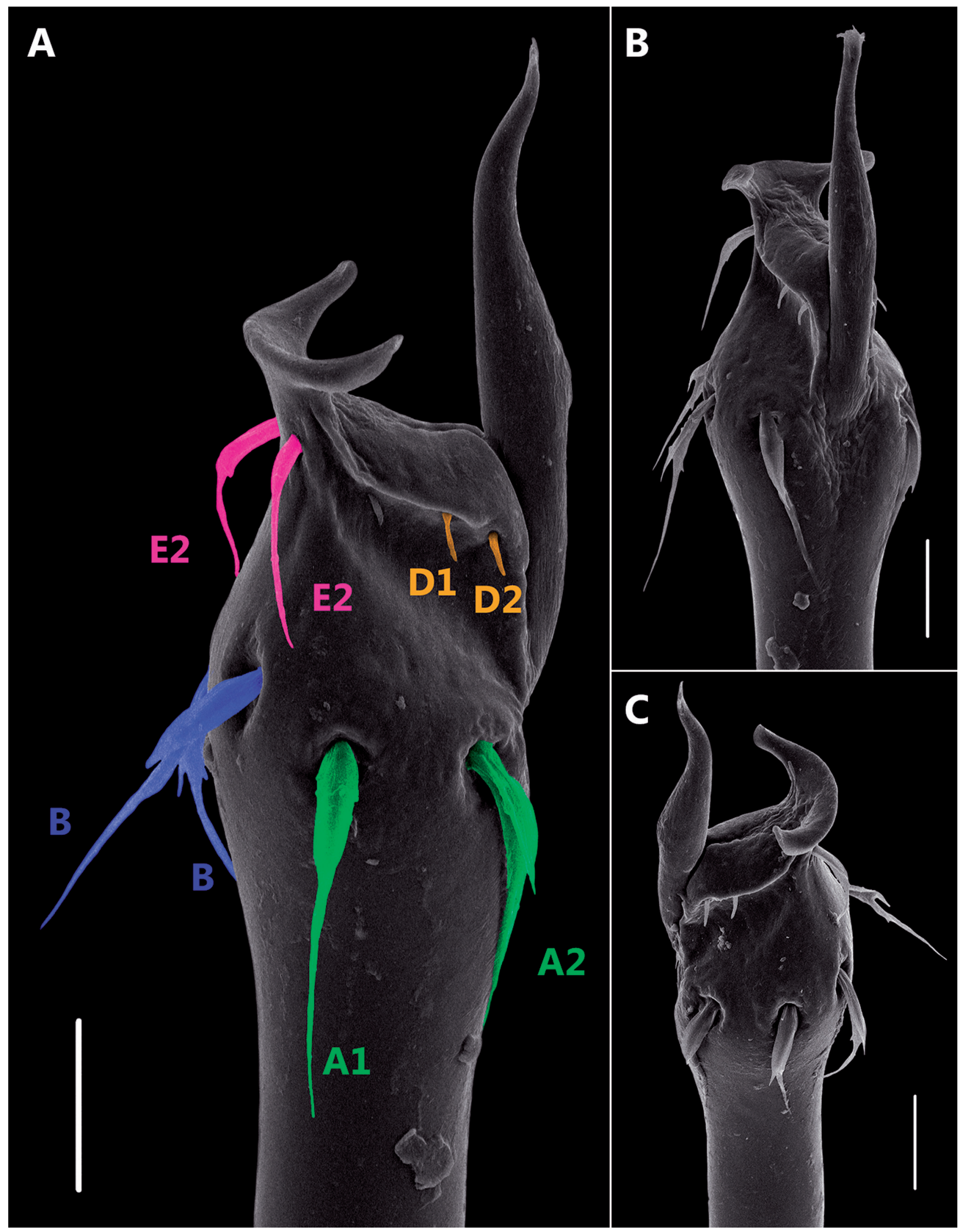

Figure 3. Distal portion of the penis of Avima tuttifrutti sp. nov. (MNRJ 59051). (A) Ventrolateral view. (B) Dorsolateral view. (C) Lateroapical view. Scale bar: $A-C=50 \mu \mathrm{m} ; \mathrm{D}=20 \mu \mathrm{m}$. Macrosetae (MS) colors: green $=M S A$, blue $=M S B$, orange $=M S D$, magenta $=$ MSE. 

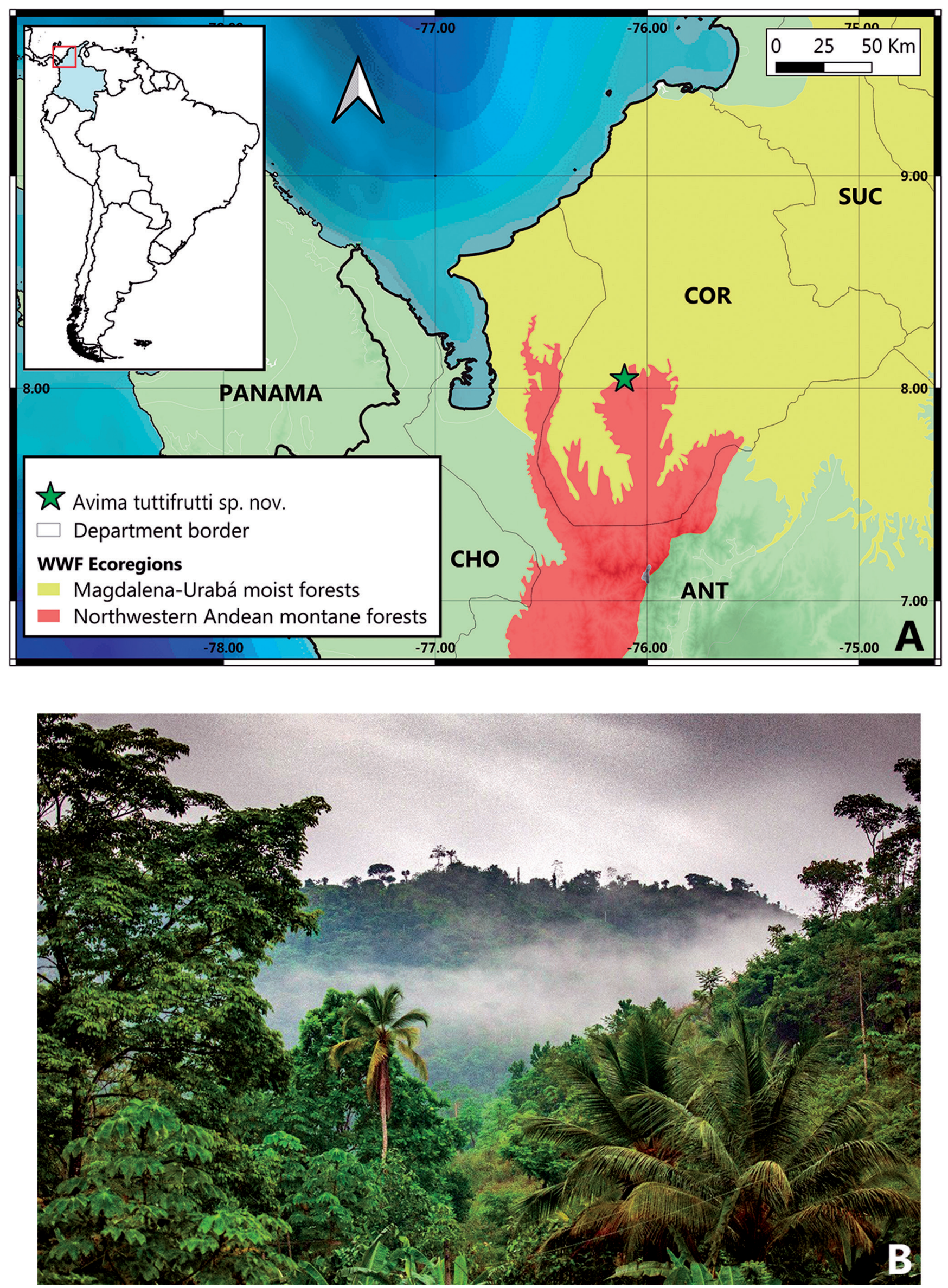

Figure 4. Geographic distribution and habitat of Avima tuttifrutti sp. nov. (A) Map showing the distribution of the new species in Córdoba, Colombia (shaded areas in the background are WWF Ecoregions). (B) Physiognomy of the forest in the type locality (photograph courtesy of Yulisa Navarro). Abbreviations: ANT = Antioquia; $\mathrm{CHO}=$ Chocó; $\mathrm{COR}=$ Córdoba; $\mathrm{SUC}=$ Sucre . 
Distribution: Known from Tierralta (Córdoba department), at $120 \mathrm{~m}$ a.s.l., in the transition area between Magdalena-Uraba moist forests (NT0137) and Northern Andean Montane Forests (NT0145) WWF ecoregions (Fig. 4A), located in Serranía de San Jerónimo (San Jerónimo Mountains, West Andes). This area corresponds to the buffer zone of the Paramillo National Natural Park (Fig. 4B), one of the less studied and most endangered protected areas in the country, mainly because of the coca crops and cattle ranching activities (Clerici et al., 2020).

Type material: Male holotype (ICN-Ao-1970) and male paratype (MNRJ 59051). Colombia, Córdoba department, Tierralta municipality, vereda Tuis Tuis, Reserva Natural Finca Tutti Frutti, [8.043333-76.100306], [120 m], on ditch with mosses; 26.iv.2019; Raquel Pastrana leg.

Etymology: The specific name is a noun in apposition taken from the type locality, Tutti Frutti farm. It is property of Mr. Agustín Hernández, who makes huge efforts to maintain the forests of this place in the middle of the expansion of cattle activities.

Remarks: The external morphology of Avima tuttifrutti sp. nov. (i.e., inconspicuous mesotergal grooves, lack of armature on mesotergal area III, presence (or not) of granules on DS), matches partially that of some species of Avima (e.g., Avima anitas Porto \& Colmenares, 2014, Avima bicoloripes Roewer, 1949, Avima matintaperera Pinto-da-Rocha, 1996 and Avima soaresorum Pinto-daRocha, 1996). However, the body coloration and the hump on area IV of the new species have not been seen in any Avima species, which easily allows its recognition as a new species. Additionally, the leg II and the penis of A. tuttifrutti sp. nov. show characters that deserve attention (for comparison, see Roewer (1949), Pinto-da-Rocha (1996) and Porto \& Colmenares (2014)).

A. tuttifrutti sp. nov. has a very long and slender leg II (Fig.1F).Forcomparison, notethedifferencesintheproportion Leg II/DS length: A. bicoloripes ( $42 \mathrm{~mm} / 4 \mathrm{~mm}=10.5$ ); A. matintaperera $(29.26 \mathrm{~mm} / 2.48 \mathrm{~mm}=11.8)$; A. soaresorum $(31.93 \mathrm{~mm} / 2.64 \mathrm{~mm}=12.1)$; . tuttifrutti sp. nov. (48.01 mm/2.61 mm = 18.4).

The stylus of $A$. tuttifrutti sp. nov. is very interesting, being mostly erect, becoming narrower from distal half and showing a sigmoidal tip (Figs. 3A, C). From the species cited above, just $A$. soaresorum has an straight stylus, but the tip is dorsally curved. The longitudinal dorsal keel is present in $A$. anitas and $A$. matintaperera, but is absent in A. tuttifrutti sp. nov. (Fig. 3 ) and A. soaresorum.

The MSE1 present in A. anitas are not present in A. matintaperera and $A$. soaresorum, nor in $A$. tuttifrutti sp. nov. (Fig. 3A). The MS A2 in A. tuttifrutti sp. nov. are located close to the base of the stylus, forming a belt around the malleus together with MS A1 and B (Figs. 3A, B). This alignment is similar to that seen in A. matintaperera and $A$. soaresorum, but opposite to that of $A$. anitas, where MS $\mathrm{A} 2$ are located far from the base of the stylus.
The presence of the MS D1-D2 in A. tuttifrutti sp. nov. (Fig. 3 ) is shared with A. anitas and A. matintaperera, but not with $A$. soaresorum.

All these morphological characteristics could suggest systematic affinities, but only a phylogenetic analysis including other Avima species and other Leiosteninae genera, would help to better understand its internal relationships.

\section{ACKNOWLEDGMENTS}

The second author is immensely grateful to Agustín Hernández, owner of Tutti Frutti farm, for the hospitality in the visit to his property. We are deeply grateful to Adriano Kury (National Museum, Rio de Janeiro, Brazil) and Jesús Ballesteros (Córdoba University, Montería, Colombia) for all the guidance, suggestions and laboratory facilities. Thanks to all the curators for allowing us to deposit the type material here described in their collections and to Yulisa Navarro for sharing with us the photograph used in Fig. 4. The suggestions of two anonymous referees greatly improved the present work. The OmniPaper Project (http:// www.museunacional.ufrj.br/mndi/Aracnologia/pdfliteratura/pdfs\%20opiliones.htm), created and maintained by Adriano Kury, was very helpful providing access to some harvestmen literature. The SEM micrographs were taken in the Microscopy Platform Rudolf Barth/IOC-FIOCRUZ (Rio de Janeiro, Brazil). This work was supported by Ph.D. scholarship from the Coordination for the Improvement of Higher Education Personnel (CAPES) to A.F.G.

\section{AUTHORS' CONTRIBUTIONS}

R.P.M. made the drawings, described the species, participated actively in the discussion and reviewed and approved the final version of the paper. A.F.G. took and edited the photographs, help with the drawings, described the species, participated actively in the discussion and reviewed and approved the final version of the paper.

\section{REFERENCES}

Ahumada-C., D.; García, A.F. \& Navas-S., G.R. 2020. The spiny Agoristenid genus Barinas (Arachnida: Opiliones), with the description of a new species from the Colombian Caribbean. Arachnology, 18(6): 632-641. D01

Clerici, N.; Armenteras, D.; Kareiva, P.; Botero, R.; Ramírez-Delgado, J.P.; Forero-Medina, G.; Ochoa, J.; Pedraza, C; Schneider, L.; Lora, C; Gómez, C.; Linares, M.; Hirashiki, C. \& Biggs, D. 2020. Deforestation in Colombian protected areas increased during post-conflict periods. Scientific Reports, 10(4971): 1-10. DOI

García, A.F. \& Kury, A.B. 2020. The Neotropical harvestman genus Vima Hirst, with description of a new species from Colombia (Arachnida: Opiliones: Agoristenidae). Journal of Arachnology, 48(1): 67-76. DOI

García, A.F. \& Villarreal, 0. 2020. Description of a new species of Leptostygnus Mello-Leitão, 1940 and notes on the male genitalia in the subfamily Leiosteninae (Opiliones: Agoristenidae). Studies on Neotropical Fauna and Environment, 55(3): 1-15. DOI 
Kury, A.B. 2003. Annotated catalogue of the Laniatores of the New World (Arachnida, Opiliones). Revista Ibérica de Aracnología, volume especial monográfico 1: 1-337.

Kury, A.B. 2013. Order Opiliones Sundevall, 1833. In: Zhang, Z.-Q. (Ed.). Animal Biodiversity: An Outline of Higher-level Classification and Survey of Taxonomic Richness (Addenda 2013). Zootaxa, 3703(1): 27-33.

Kury, A.B. 2018. Familial nomina in harvestmen (Arachnida, Opiliones). Bionomina, 13(1): 1-27. DOI

Kury, A.B. \& Medrano, M. 2016. Review of terminology for the outline of dorsal scutum in Laniatores (Arachnida, Opiliones). Zootaxa, 4097: 130-134.

Kury, A.B. \& Villarreal, M.0. 2015. The prickly blade mapped: establishing homologies and a chaetotaxy for macrosetae of penis ventral plate in Gonyleptoidea (Arachnida, Opiliones, Laniatores). Zoological Journal of the Linnean Society, 174(1): 1-46. D0I

Olson, D.M.; Dinerstein, E.; Wikramanayake, E.D.; Burgess, N.D.; Powell, G.V.N.; Underwood, E.C.; D'amico, J.A.; Itoua, I.; Strand, H.E.; Morrison,
J.C.; Loucks, C.J.; Allnutt, T.F.; Ricketts, T.H.; Kura, Y.; Lamoreux, J.F.; Wettengel, W.W.; Hedao, P. \& Kassem, K.R. 2001. Terrestrial ecoregions of the world: A new map of life on Earth. BioScience, 51(11): 933-938. D0I Pinto-da-Rocha, R. 1996. Notes on Vima insignis Hirst, 1912, revalidation of Trinella Goodnight and Goodnight, 1947 with description of three new species (Arachnida, Opiliones, Agoristenidae). Revista Brasileira de Entomologia, 40(2): 315-323.

Porto, W. \& Colmenares, P. 2014. A new species of Avima, the first record of Agoristenidae (Opiliones: Laniatores) from the state of Roraima, Brazil. Zoologia, 31(6): 634-638. DOI

QGIS Development Team. 2018. QGIS Geographic Information System. Open Source Geospatial Foundation Project. Available: http://qgis.osge0.org. Access: 19/06/2018.

Roewer, C.F. 1949. Über Phalangodiden I. (Subfam. Phalangodinae, Tricommatinae, Samoinae.) Weitere Weberknechte XIII. Senckenbergiana, 30(1/3): 11-61. 